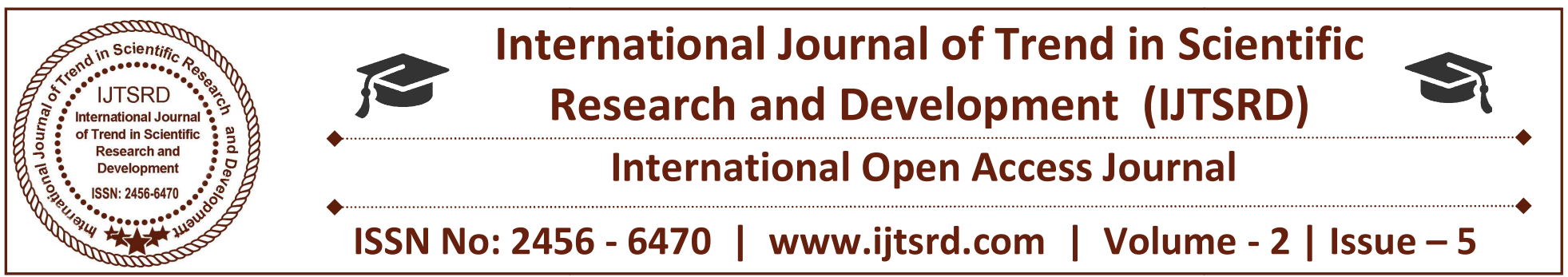

\title{
Demonetisation-Challenges in Cashless Economy
}

\author{
V.S. Krishna \\ Shanmugha Arts, Science, Technology \& Research Academy \\ Thirumalaisamudram, Thanjavur, Tamil Nadu, India
}

\begin{abstract}
One contemporary issue that has shook the nation in its entirety is Demonetisation. Demonetisation is an economic policy which literally means "replacement of old currency unit with a new currency unit". It is the process to curb the issue of tax evasion, to eliminate corruption, black money, counterfeit currency and terror funding. Here, Economic policy refers to the actions taken by the government for setting levels of taxation, Government budgets, money supply \& interest rates and other areas of government interventions into the economy. This article examines the policy of Demonetization from the standpoint of the noble object it purports to achieve and provides an insight on the positive and constructive effects that the policy has had on the economy.
\end{abstract}

Keywords: Demonetisation, economic policy, government, currency notes, black money

\section{INTRODUCTION}

India is a cash-based economy in which $98 \%$ of the transaction by volume and $65 \%$ by value are made using cash. With no demonetisation since 1980's, the tax evaders have hoarded a lot of money. ${ }^{1}$ In India, only $3 \%$ of the total population pays Income Tax and of that $66 \%$ file nil return. In order to better the revenues for the improvement of the country, as it is a growing superpower, this demonetisation process has been introduced for the third time. The process is like a two faced coin where on one side it puts a huge dent in the black economy but on the other hand, worst case scenario, it disrupts the cash flow in the country. The implementation of this policy is not for a certain

\footnotetext{
${ }^{1} \mathrm{http}$ //awordtotheworld.com/need-know-demonetization-india-

number of people, but for the public as a whole. When a certain economic policy has been introduced for the welfare of the general public, initially there would be certain drawbacks mostly temporary and are intended to smooth out on the long run. Some of the temporary drawbacks of this economic policy are:

$>$ Due to the cash crunch in the economy there were losses to small vendors.

Many people did not have bank accounts in the rural areas.

But the main benefits due to the introduction of this economic policy for the nation are:

It will help to stop the circulation of the counterfeit currency.

By the sudden demonetisation of high denomination currency, it would lead to the hoarders of black money having no immediate recourse.

$>$ Untaxed amounts of cash and money present into foreign hidden deposits should come to light.

Tax evasion cases can be reduced.

$>$ The biggest benefit for the nation is that people moving towards a digital economy brings out transparency in terms of their transactions which would lead to complete accountability.

When $86 \%$ of a country's currency has been squeezed out of the market and sought to be replaced by the introduction of a new currency, there would obviously be significant consequences of that decision. That particular decision, in the current scenario was made by the government on November $8^{\text {th }} 2016$.

The word Demonetisation was first used by the French in the years $1850-1855$. Since then many countries including India started using the word as 
well as the policy. India has been demonetized three times: First time on $12^{\text {th }}$ January 1946, Second time on $16^{\text {th }}$ January 1978 and Third time on $8^{\text {th }}$ November 2016.

\section{FIRST DEMONETISATION POLICY OF 1946:}

It was a drastic step taken by the Reserve Bank of India when this demonetisation policy was first announced on $12^{\text {th }}$ January 1946 . On $11^{\text {th }}$ January 1946, the Government announced that notes of Rs 500,1000 and 10,000 will cease to be legal tender from the next day. As this economic policy was introduced first time in India, there were repercussions similar to people dying of shock but there were exceptions of long lines at the bank and the middle classes being hit because this ban did not have much impact as the currency of such higher denominations were not accessible to the common people. Rs 500 and Rs 1000 notes were introduced in 1934 and after four years in 1938, Rs 10,000 notes were introduced. However, both the notes i.e., Rs 1000 and Rs 10,000 were reintroduced after the first demonetisation in 1954 with an additional introduction of Rs 5,000 currency. As there wasn't any access of higher denominations to the common people, the old notes were being sold at 60 and 70 percent of their price. This drastic move was called as a "Death Blow" to the black marketers. However, this measure did not succeed as it was the time when the World War II had just ended. It was also the time where the Government of India had passed an ordinance on High Denomination Bank notes in lieu of the businessmen in India who had made huge fortunes by supplying the Allied war efforts and were concealing the profits from the tax department. As the saying goes "The rich becomes richer and the poor becomes poorer". The money that is concentrated in the hands of the rich people is not just simply wealth; it is the life blood of thousands of Indians who starved to death while the black marketers went on piling up the money in their safes. This was also not a successful measure because its main purpose of eradication of Black -marketing was not effective. There was absolutely no way to determine if a particular note brought by an individual could be proved as black money or white money. In the end, the exchange of Rs 143.97 crores was replaced by new notes of lower denomination of Rs 134.9 crores, making only Rs 9.07 crores demonetized, partially successful because it mostly became a "conversion scheme" rather a "Demonetisation scheme".

\section{DEMONETISATION POLICY OF 1978:}

The first measure did not have much impact as it was the pre-Independence period and it was the time when the World War II had just ended. This Demonetisation policy was again introduced for the second time in January 1978. This policy was implemented right after the emergency was lifted from India by the First non-congress Government in Independent India by the Gujarat Prime Minister Morarji Desai who led the Janata Parivar Government. This Second step in demonetisation policy had much greater impact than the first one. The announcement of this economic policy was done by R. Janaki Raman, a senior official at Reserve Bank of India on $16^{\text {th }}$ January 1978 at 9 AM on The All India Radio. It was also added that all banks and treasuries would be closed on the next day i.e., $17^{\text {th }}$ January 1978 . This created havoc among the public. The main motive here also was to curb the black money menace and make a comeback from the Emergency period problems by starting afresh for the betterment of the Indian economy. It was more of a "January demon" because it was just 4 days before in 1946 when the First demonetisation policy had taken place. This time the Indian Government had demonetized Rs 1000, 5000 and 10,000 denominations in a bid to counter black money in the economy. This Demonetisation policy of high denomination bank notes was a primarily aimed at controlling illegal transactions where series of measures had been taken against the anti-social elements. Before the implementation of this economic policy the Wanchoo Committee in the early 1970s had recommended the Government to withdraw the currency of higher denominations because the country had been going through a difficult period. Here, the difficult period mentioned by the Wanchoo Committee is the day our country's currency value dropped drastically i.e., on $6^{\text {th }}$ June 1966 . Due to this, there was lack of purchasing power by underdeveloping countries in US Dollars. In 1950s and 1960s the trade deficits had reached an all time high. Despite India winning the Indo-Pak war in 1965, the military expenditure pushed our inflation close to $7 \%$. At that time, the trade deficit was close to Rs 950 crores. Then the Honorable First Women Prime Minister of India, Mrs. Indira Gandhi announced about the devaluation of the Indian Rupee pegged at Rs 4.75 to Rs 7.50 per US Dollar, which is $57 \%$ of devaluation. This move had reduced the trade deficit to Rs 100 crore. Due to this devaluation of the Indian Rupee, the value of the Indian Rupee was lost. During the 1950s and 1960s Indian Rupee was the major 
currency used in the Middle East. Due to the severe fluctuation in the Indian currencies, countries like Kuwait in 1954 and Oman in 1971 started adopting their own currencies. The main reason for adopting its own currency is that Kuwait became extremely rich from 1950 s to 1980 s due to the oil discovery and Oman also became rich after the governance change in the country and oil discovery. During 1977-78, around Rs 73.1 crore was demonetized. Soon after the Emergency period in 1977, Indira Gandhi's Government was brought down due to lack of political, economic and social stability. However, coming to the initial agenda i.e., the implementation of demonetisation in 1978 didn't succeed. This was because Rs 10,000 was barely used by the common people. The main reason for the failure of this economic policy in 1978 is that before the announcement of the policy, there were rumors about the implementation of this policy which made the black money hoarders alert and to store their money in lower denominations.

\section{A PATH-BREAKING MEASURE TO CURTAIL THE MEASURE OF BLACK MONEY:}

Demonetisation of currency is not entirely effective because one can't really know how much black money is there in circulation. Black money in the form of high-value currency is much less than black money as untaxed income, part of which might be invested in expenditure which can be used for investment in real estate, commodities, stocks, benami lending or plain graft to secure political or administrative goodwill. There wasn't much impact from the implementation of this demonetisation policy during the time of 1946 and 1978. The total bank notes in circulation in India as on $28^{\text {th }}$ October 2016 were 17.77 lakh crore. In terms of value, the annual report of the Reserve Bank of India as of $31^{\text {st }}$ March 2016 stated that the total bank notes in circulation valued to 16.42 lakh crore of which nearly $86 \%$ was Rs 500 and 1000 banknotes. In terms of volume, the report stated that $24 \%$ of the total 90,266 million banknotes were in circulation. In 2014, the Government had announced under the Pradhan Mantri Jan Dhan Yojana about the zero-balance account for all the citizens of India along with RuPay Debit Cards, OD facility and many more things for the welfare of the public. This was done in order to bring about financial inclusion in the country. The Government had announced Insurance and Pension schemes for lifetime which resulted in large number of citizens standing in front of banks to open new bank accounts. After the launch of scheme, there were 18 lakh accounts opened in the first week where Rs 50 Billion was received as deposits from these accounts. Income Declaration scheme had been introduced by the Government in 2016 in which the black money could be made white by paying $45 \%$ tax on the total amount. It had also given a deadline and had also promised to keep the data confidential. The Government had made it mandatory for all the gold buyers worth above Rs 2 lakh to furnish PAN account details. In the meanwhile, GST bill had been passed by the Upper House.

After, the introduction and implementation of various schemes by the Government, a drastic step was again implemented on $8^{\text {th }}$ November 2016 at 8 pm by demonetizing Rs 500 and 1000 denominations and introducing new Rs 500 and 2000 banknotes. This was the third time where India was again demonetized which was unexpected. There was hue and cry after the announcement made by the Government about the sudden demonetisation process which led to a lot of chaos. The announcement was made by the Prime Minister himself rather by the Reserve Bank of India. Due to the sudden implementation of this economic policy most of the businesses were shut down for the day and people started wrapping up from their day's work, especially the Black money hoarders. After the implementation of this economic policy, Banks remained closed the next day paralyzing the country. The Black money hoarders couldn't find a way out to channel the money, making it a fool proof plan to nab all the hoarders under the tax radar. Though the implementation of this policy came out as a bombshell, but it seemed that Government was well prepared to handle the situation. Except the Finance Minister and top officials of the Reserve Bank of India, no one else had the news about this demonetisation process before the announcement made by the Prime Minister. Before the implementation of this policy, the Prime Minister had got most of the unbanked sector into the banking ecosystem by the Jan Dhan Yojana with the Rupay Cards. He also gave an opportunity without extension through the Income Declaration Scheme to curb the black money. After the announcement, there was immediate response from the people. People immediately thronged to the nearest ATM's like Industrial Bank, which gives you denominations of your choice and deposit money through the cash depositor machine. There was a mad rush and queue at the major petrol pumps in the cities, when the 
government had announced about accepting old denominations in places like petrol pumps ( PSU owned ), hospitals, airports, bus stands, railway stations etc till $11^{\text {th }}$ November 2016. NHAI toll roads were lined up with heavy traffic due to the lack of change. After looking through this mad rush and thronging, the government officials had decided not to charge toll on National Highways till the midnight of November $18^{\text {th }} 2016$. This decision had been taken by the officials for the smooth traffic movement across all National Highways and to provide relief to the cash-starved people who were queuing up outside the ATM's after the implementation of demonetisation. In the interest of the general public the Reserve Bank of India had waived charges for ATM transactions from $10^{\text {th }}$ November 2016 till 30 ${ }^{\text {th }}$ December 2016 for both financial and non- financial transactions at one's own bank as well as others. In order not to create a lot of chaos the officials had decided to keep all the banks open for the public after the implementation of the demonetisation process on $12^{\text {th }}$ November 2016 (Saturday) and $13^{\text {th }}$ November 2016 (Sunday). All the black money hoarders tried to convert old denominations into gold and silver. After seeing a surge in the gold shops the Government officials started raiding the shops for proper documents made for the purchases of gold, thereby closing another window for the hoarders. Many people thronged to airports and railways to book high-class advance tickets so that they can claim refund later from the same. The Government later declared no-refund for the purchase of tickets made using old denominations which again closed another window for the hoarders. With several years of persistent inflation and economic growth, the money in circulation was to rise for sure. According to Reserve Bank of India, Rs 14.265 trillion in currency notes was in circulation as on $20^{\text {th }}$ March 2015, which accounted for $12.3 \%$ of India's Gross Domestic Product (GDP). There were 15.7 billion notes of Rs 500 and 6.3 billion notes of Rs 1000 in circulation in India, which brings a total of 22 billion notes which has to be junked after $8^{\text {th }}$ November 2016.It was said that Rs 1000 was the cheapest note produced in India. The absolute cost of printing the higher denominations is more, but as a percentage of the face value of the note, the lower denominations become more costly. Rs 1000 note required only 0.32 percent of its face value to produce but a Rs 100 note requires 1.8 percent of its face value, Rs 50 note 3.6 percent and Rs 10 note 9.6 percent to print.
Due to the implementation of this economic policy, many politicians started accusing the government but the common people didn't have any problems. This move will also have a positive by product such as Individuals and households with no bank accounts, keeping all the income in cash and at homes, have to create bank accounts to deposit money, making financial inclusion indirectly inevitable. $86 \%$ of the public had no problem with this issue as it was for the good cause. The other $14 \%$ of the people like politicians started alleging statements such as they weren't informed; Farmers and housewives were affected due to this policy etc. Though the allegations and accusations made by many politicians were true to an extent but the main motive of the implementation of this policy was for the welfare of the public. When any policy is implemented, initially there would be repercussions for a certain period of time but in the long run it would be for the betterment of the country. When the Government had implemented this Demonetisation policy, it wasn't for his personal benefit but in the interest of the general public. This move got him a lot of perspective points from the layman who sees political parties promising to end corruption but never do it. The fact is that black money in cash, accounts to only $6 \%$ of the total black money in India with the rest being in the form of gold, properties in fictitious names, loss -making fake companies etc.

The two main problems which came to an end were Hawala racket and rise in property prices. Hawala is the way of transferring money from a different country to India in Indian denominations. Although it is illegal, the people in this racket make their money white through this process in different countries. But after $8^{\text {th }}$ November 2016, where the government scrapped all the high denominations, making the notes lying with the Hawala traders null and void. ECommerce firms like flipkart and snapdeal stopped cash on delivery transactions but in order to support the government's decision. The Government had also made the new notes Rs 500 and 2000 available from $11^{\text {th }}$ November 2016 so as to have a ready alternative for the people. Due to the sudden implementation of this economic policy, the Standard and Poor Biggest Stock Exchange declined 6.1 percent to 25,902 while the National Stock Exchange Nifty lost 6.3 percent to 8,002 . The market breath was abysmal at 1,448 declines, 69 advances and 325 stocks which remained unchanged. Shares were tumbling across Asia. The dollar had plunged against yen, dropping to 101.99 
yen from 105.46 yen. The Mexican peso had also fallen 10.7 percent to 20.32 pesos to the dollar.

In order to support this economic policy, Digital Payments giant, Paytm had put out large scale advertisements to promote cashless payments for major transactions which are still prevailing now in many general stores for small purchases, petrol pumps, Auto's and Highway toll booths - as getting change back was a hassle etc. There have been less incidents reported on stone pelting and protests in the Kashmir valley. Demonetisation has played a major role in making fake Rs 500 and 1000 notes as a void tender. Due to the implementation of this demonetisation policy, the Government has got more time to come up with better solutions in order to maintain peace and harmony in the valley. ${ }^{2}$

Some people started making accusations and posing questions as to whether there is need for new Rs 2000 note and whether it is an encouragement for the black money hoarders to pile up more money in less space.

The main reason for this Demonetisation policy in 2016 is to control the black money. Rs 1000 note was released in 2000 to cater the demands high-value transactions. By calculating the inflation in 15 years, the Rs 1000 is valued at Rs 7500 approximately in 2016 and Rs 500 in 2000 is valued more than Rs 2000 in 2016. In order to achieve a cashless economy, there should be more number of Rs 2000 bank notes in the market. In order to avoid making of fake currencies, there was a new feature included for the verification of the originality of Rs 500 and 2000 note by viewing at $45 \mathrm{o}$, which also supports the visually impaired people with Braille imprint, etc. The new bank notes also had its value written in Konkani along with various languages.

There were also questions posed and petitions filed by few people as to whether this policy had been of excessive delegation to the Reserve Bank of India.

The basic function of the legislature is law making. Here, the legislature has not delegated that to the Reserve Bank of India as it had already made a statute governing RBI. The Legislature in that said act had

\footnotetext{
${ }^{2}$ http://awordtotheworld.com/unknown-facts-about-

demonetization-1946-1978-and-2016
}

given the power to the RBI to demonetize the currency which is clearly stated in Reserve Bank of India Act, 1934 under Section 26 (2). This cannot be held as excessive delegation because in any country the monetary policy is controlled by the RBI and the circulation of money supply in the economy is a monetary policy and the RBI being the Central Bank of the country is a competent body to demonetize the currency. There exists plethora of cases to prove that it is not excessive delegation.

\section{State of Rajasthan and Ors Vs BasantNahata: ${ }^{3}$}

In this case there was a question raised as to whether the public policy could be the subject matter of delegation of essential legislative function, but the court opined: There cannot be any doubt whatsoever that the court shall not invalidate a legislation on the ground of delegation of essential legislative function or on the ground of conferring unguided, uncontrolled and vague powers upon the delegate without taking into account the preamble of the Act as also other provisions of the statute in the event they provide good means of finding out the meaning of the offending statute.

\section{Gwalior Rayon Case: ${ }^{4}$}

In this case, the court held that, so long as a legislature can repeal the statutory provision, it does not abdicate its legislative function; it retains control over the delegate and delegation should be deemed valid howsoever broad the delegated legislation may be.

But in the current scenario, The Reserve Bank of India had taken a very extreme step to curb the black money for the betterment of the public which was under the procedure established by law and this decision or step taken by the RBI was implemented by the government.

There were also issues raised and petitions filed by certain people as to whether the court had the power to sit in the Judgment over such matters concerning economic policy.

This is because a policy decision, when not found to be arbitrary or based on irrelevant considerations or mala fide or against any statutory provisions, does not call for any interference by the Courts in exercise of

\footnotetext{
${ }^{3}$ (AIR 2005 SC 3401) (supra)

${ }^{4}$ (1988 (34) ELT 562 MP)
} 
power of judicial review. This principle of law is ingrained in stone which stated that policy decision can be interfered only when it is contrary to provisions of Constitutions or any law or such policy itself is wholly arbitrary. There exists plethora of cases to prove that the court didn't have the power to judge on economic policy issues.

\section{VillianurIyarkkaiPadukappuMaiyam Union of India and Ors: ${ }^{5}$}

Vs

In this case the Court held that, in matters relating to economic issues the Government has, while taking a decision, right to "Trial and Error" as long as both trial and error are bona fide and within the limits of the authority. For testing the correctness of the policy, the appropriate forum is Parliament and not the courts. The court cannot lightly assume that the action taken by the Government is unreasonable or against public interest because there are large number of considerations, which necessarily weigh with the Government in taking an action.

\section{Zippers Karamchari Union Vs Union of India \& Ors: ${ }^{6}$}

In this case the court held that the in the matters of trade and commerce or economic policy wisdom of Government must be respected and Courts cannot lightly interfere with such policy decisions. The court also held that policy decision can only be interfered when it is contrary to provisions of the Constitution or such policy itself is wholly arbitrary.

$>$ Peerless General Finance and Investment Co. Limited and Anr. etc. Vs Reserve Bank of India etc $^{7}$

In this case it was held that, the function of the Court is not to advise in matters relating to financial and economic policies for which bodies like Reserve Bank of India are fully competent. The Court can only strike down some or entire directions issued by the Reserve Bank in case the Court is satisfied that the directions were wholly unreasonable or violative of any provisions of the Constitution or any statute. It would be hazardous and risky for the courts to tread an unknown path and should leave such task to the expert bodies.

\section{$>$ R.K.Garg Vs Union of India: ${ }^{8}$}

In this case the court held that laws relating to economic activities should be viewed with greater latitude than laws touching civil rights such as freedom of speech, religion, etc. It was observed that the legislature should be allowed some play in the joints because it has to deal with complex problems which do not admit of solution through any doctrinaire or st(sic)-jacket formula and this is particularly true in case of legislation dealing with economic matters, where, having regard to the nature of the problems required to be dealt with, greater play in the joints has to be allowed to the legislature.

\section{Tamil Nadu Housing Board and Ors. Vs Sea Shore Apartments Owners Welfare Association: ${ }^{9}$}

In this case also it was held that it was not the function of the Court to sit in judgment over such matters of economic policy as must be necessarily left to the Government to decide. The experts alone can work out the mechanics of price determination; Court can certainly not be expected to decide without; the assistance of the experts.

There were also questions posed as to whether the legislature can be challenged on the ground of unreasonableness.

Here, the questions raised were supported by some decided case laws.

\section{McDowell \& Co. and Ors: ${ }^{10}$}

In this case it was held that when a state legislature can be restricted. A law made by Parliament or the legislature can be struck down by courts only on two grounds alone, (1) lack of legislative competence and (2) violation of any of the fundamental rights guaranteed in Part III of the Constitution or of any other constitutional provision. There is no third ground. No enactment can be struck down by just saying that it is arbitrary or unreasonable. An enactment cannot be struck down on the ground that court thinks it unjustified. Parliament and the legislatures, composed as they are of the representatives of the people, are supposed to know and be aware of the needs of the people and what is good and bad for them.

\footnotetext{
${ }^{8}$ (1981 (4) SCC 675)

${ }^{9}((2008) 3$ SCC 21)

${ }^{10}$ ((1996) 3 SCC 709)
} 
$>$ Ashoka Kumar Thakur Vs Union of India and Ors: ${ }^{11}$

In this case the Court held that legislation cannot challenge simply on the ground of unreasonableness because that by itself does not constitute a ground. The validity of a constitutional amendment and the validity of plenary legislation have to be decided purely as question of constitutional law.

Furthermore, there were allegations as to whether there is discrimination in the implementation of the policy.

In Ram Krishna Dalmia Vs Shri Justice S. R. Tendolkar and Ors ${ }^{12}$ it was held that, "There is always presumption in favour of the constitutionality of a statute and the burden is upon him who attacks it to show that there has been a clear transgression of constitutional principles.

The presumption may be rebutted in certain cases by showing that on the fact of the statute, there is no classification and no difference peculiar to any individual or class and not applicable to any other individual or class, and yet the law hits only a particular individual or class"

Here in this policy, on the fact of the statute it does not classify and also in practice this policy does not classify individuals as it was implemented towards the whole country and does not only hit a certain class of people and there is no discrimination in the implementation of the policy.

In Ramprasad NarainSahi Vs The State of Bihar ${ }^{13}$ it was held that, A statute may not make any classification of the persons or things for the purpose of applying its provisions but may leave it to the discretion of the Government to select and classify persons or things to which its provisions are to apply. In determining the question of the validity or otherwise of such a statute in court will not strike down the law out of hand only because no classification appears on its face or because a discretion is given to the Government to make the selection or classification but will go on to examine and ascertain if the statute has laid down any principle

\footnotetext{
${ }^{11}((2008) 6 \mathrm{SCC} 1)$

12 (AIR 1958 SC 538)

13 ((1953) 4 SCR 1129)
}

or policy for the guidance of the exercise of discretion by the Government in the matter of the selection or classification. After such scrutiny the court will strike down the statute if it does not lay down any principle or policy for guiding the exercise of discretion by the Government in the matter of selection or classification, on the ground that the statute provides for the delegation of arbitrary and uncontrolled power to the Government so as to enable it to discriminate between persons or things similarly situate and that, therefore, the discrimination is inherent in the statute itself. In such a case the court will strike down both the law as well as the executive action taken under such law as it did in State of West Bengal Vs Anwar Ali Sarkar ${ }^{14}$, Dwarka Prasad LaxmiNarain Vs The State of Uttarpradesh ${ }^{15}$ and Dhirendra Krishna Mandal Vs The Superintendent and Remembrances of Legal Affairs. ${ }^{16}$

After the implementation of this Demonetisation policy, there were accusations made and the biggest question posed as to whether it is under the procedure established by law.

In A. K. Gopalan Vs State of Madras ${ }^{17}$ it was held that the expression "Procedure established by law" means procedure enacted by a law made by the state. The Supreme Court, by a majority, rejected the argument that the "Law" in Article 21 of the Constitution is used in the sense of jus and lex the just law and that it means the principles of natural justice on the analogy of "due process of law" as interpreted by the American Supreme Court. That in effect amounted to holding that Article 21 was a protection only against the executive and not against the legislature.

The word 'life', 'personal liberty' and 'procedure established by law' were debatable among the members of the Constituent Assembly. The most important words in this provision are procedure established by law. Judicial activism can be attributed to the court to merely two of its path breaking, pioneering decisions viz., Maneka Gandhi Vs Union of India ${ }^{18}$ and Sunil Batra Vs Delhi

\footnotetext{
${ }^{14}$ (1952 CriLJ 510)

${ }^{15}$ ((1954) 1 SCR 803)

${ }^{16}$ ((1955) 1 SCR 224)

${ }^{17}$ (AIR 1950 SC 27)

${ }^{18}$ (AIR 1978 SC 597)
} 
Administration. ${ }^{19}$ The Constituent Assembly on the issue of whether 'due process of law' should be the guiding beacon for Article 21 and its rejection, the Supreme Court in Maneka Gandhi Vs Union of India held that procedure established by law meant procedure that eventually was reasonable fair and just. This decision rendered void the plain and simple meaning of 'procedure established by law 'and introduced for the first time the grand canon of 'due process of law'.

This policy follows a clearly established procedure established by law as the procedure established by law is the RBI Act, 1934 and the provision that empowers demonetisation is Section 26 (2) and this provision allows a notification to be passed by the Central Board and this procedure is clearly followed and even in the subsequent notifications all of them were amendments to the original notification and not new notifications. This provision has already been proved constitutional in Jayantilal Ratanchad Shah, devkumar Gopaldas Aggarwal and others Vs Reserve Bank of India and others. ${ }^{20}$

In the previously mentioned case, a petition was filed challenging the constitutional validity of the High Denomination Bank Notes Act, 1978 on the grounds that it was violation of the right to carry on trade and commerce and it amounted to a compulsory acquisition of property without compensation by the Government which is clearly stated under Article 19 (1) (f) [now Article 300A] and Article 19 (1) (g) of the Constitution of India. The Constitutional bench of Supreme Court while rejecting the above contentions held that Demonetisation law was implemented in the larger public interest. Control of the problem of "unaccounted money" in any way does not amount to a violation of the right.

Essential elements of Reasonable Restrictions:

$>$ It must be imposed only on the authority of law.

$>$ It must be Reasonable.

$>$ Restrictions imposed must be specifically mentioned in these clauses.

$>$ Subject to judicial review on two grounds,

First, if the restriction is reasonable or mentioned in the clauses and Second, the purpose of such restriction (Subject to Judicial Scrutiny)
In this Demonetisation policy all the above essential elements are followed objectively and that economic policies are not allowed to be wholly arbitrary and that the economic policies must be viewed with greater latitude than laws touching civil rights. There has to be a nexus between the restriction and the object sought to be achieved and the object must not, itself, be repugnant to the letter or the spirit of the Constitution. The object sought to achieve is the eradication of black money and it by itself is not repugnant to the spirit of the constitution. In order to be reasonable the restriction must have a reasonable relation with the object which the legislation seeks to achieve, and must not go in excess of that object. The reasonableness of a restriction has to be determined in an objective manner and the standpoint of the interest of the general public and not from the point of view of the person upon whom the restrictions are imposed. Hence, Restriction can be said to be in the Interest of the public order only when the nexus between the restriction and the public order is direct and proximate.

\section{CONCLUSION:}

In order to conclude, this Demonetisation policy has only been implemented for the welfare of the public and not for a particular person or for personal gain or private profit. There are only two possible ways this could play out for the country. Either this move by the $\mathrm{PMO}$ ends in affecting the Black money issue targeted by the government or could very well be the foundation supporting the transition from a cash dependent economy to a cashless or a digitalized economy.

\section{BIBLIOGRAPHY:}

www.manupatra.com

www.scconline.in

www.firstpost.com

www.thequint.com

\footnotetext{
${ }^{19}$ (AIR 1980 SC 1579)

${ }^{20}$ (AIR 1997 SC 370)
} 